\title{
Resignation of Regional Head and/or Vice in the Tenure: Politics of Law and Democracy Perspectives
}

Imam Ropii ${ }^{1}$, Hibertus Sujiantoro ${ }^{2}$

\author{
1 Faculty of Law, Universitas Wisnuwardhana Malang \\ mamiku01667@gmail.com \\ 2 Faculty of Law, Universitas Wisnuwardhana Malang \\ arum_suji@yahoo.com
}

\begin{abstract}
Introduction to The Problem: The resignation of the regional head and/or vice today is a serious problem, both in the perspective of democracy, law, and even budget politics. Run as regional head and/or vice is a right, but maintaining the mandate after being elected is an obligation. It is compounded by the political direction of the law, which creates a pragmatically oriented political configuration, thus facilitating the resignation process. Of course, this atmosphere, in addition to injuring constituency, also contradicts democracy and the direction of its legal goal. Purpose/Objective Study: This research is based on two problem formulations, first, how is the regulation related to the resignation of the regional head and/or vice in the perspective of legal politics? Second, how are the resignation of the regional head and/or vice seen from a democratic perspective?

Design/Methodology/Approach: This research uses a juridical-conceptual approach with a multidisciplinary method. The secondary data is analyzed qualitatively both on a juridical basis (legislation) and conceptually (democratic construction) so that the results will be obtained not only descriptive but also prescriptive.

Findings: The regulations that are formed are still very pragmatic in the interests of the party. Therefore, the political configuration is still a preference to accommodate the rights and interests of political elites who seem oligarchic. Furthermore, this attitude of resignation also does not reflect the attitude of a democrat because it only focuses on his rights and annuls his obligations.
\end{abstract}

Paper Type: Research Article

Keywords: Resignation; Regional Head; Politics of Law; Democracy

\section{Introduction}

The regional head election system in Indonesia is not explicitly stated, whether directly elected by the people or elected by local representatives (members of the DPRD). The Constitution only states, "regional heads consisting of Governors, Regents and Mayors as respective heads of provincial, district and city-regional governments are democratically elected" (Article 18 paragraph 4 of NRI Constitution). The word democratic itself indicates a condition that must fulfill the legality requirements, 
openness, and the implementation of a democratic system. Unlike the Regional Head Election, the method of electing the President and Vice President is carried out directly as stipulated in Article 6A paragraph (1) of the 1945 Constitution of the Republic of Indonesia.

The legal politic wanted to be built during the amendment of the 1945 Constitution of the Republic of Indonesia because the construction of democracy itself has a variety perception, so it must be 'locked' with clear regulations or laws so it won't be multiple interpretations. The provisions of Article 65 paragraph (1) of Law Number 32 of 2004 concerning Regional Government itself are more general, but Article 24 paragraph (5) states that the people directly elect regional heads and regional vice heads in the area concerned. However, the problems are at Article 103 paragraphs (3) and (4) then the control over the determination of the position is still in the Regional Representatives (DPRD). It puts the election process itself is not purely 'election' but rather 'selection', which is strongly flavored 'election' (M. A. Aziz, 2016). It is because the committee does not have the authority that must be passed on to other institutions.

In 2014 the government issued a Substitute Law No. 1 of 2014 concerning Election of Governors, Regents, and Mayors, which was later stipulated by Law Number 1 of 2015. In contrast to Law Number 32 of 2004, which places Regional Election (Pilkada) as a 'selection' quasi 'election'. Then the legal politics of Law No. 1 of 2015 accommodate a direct election regime purely because the committee Regional General Elections Commission (Regional KPU) has the authority to determine who wins the election without the approval of the Regional Representatives (DPRD). It needs to be understood that the political configuration influences not only the realm of regulation-making but also its enforcement (Khakim, 2016).

Direct election is also mentioned as a principle when looking at the provisions of Article 2 of Law Number 1 of 2015, which states, "Election is conducted democratically based on the principle of direct, general, free, confidential, honest, and fair." Based on this principle, regional elections cannot be done directly by the people of the region; thus, it involves many parties, such as election executors, security officers, voters, polling stations, and a lot of election budget. The process and procedure of direct election becomes essential to be highlighted because it is one of the barometers of the state which is said to be democratic or not.

This direct electoral system, built the legal politics that are Regional Leaders not only gain constitutional legitimacy but also sociologically. Because their leaders in the next 5 (five) years are their own choice; thus, they are expected to meet their expectations. Mokhamad Abdul Aziz (M. A. Aziz, 2016) Regional Election's regulation must lead to the main goal, which is getting a qualified regional head. Besides, the results of the elections must also be able to deliver the society to be a better social, political and economic conditions (Akbar, 2017). 
Direct election gives legitimacy to regional heads and vice both juridical and social legitimacy. Still, it turns out these two legitimacies cannot correctly 'bind' them to complete their mandate to completion. The position of the regional head or vice also used as a 'stepping stone' for higher political office, and formally-legally this was legitimate. It means that no regulation prohibits the regional head or vice from stopping/resigning when he will jump to get a higher political position and prestige. Due to no applicable law regarding the prohibition of regional heads or vice to resign during their tenure has resulted in uncertainty law (Santoso, 2007). Referring to the provisions of Article 78 paragraph (1) of Law Number 23 of 2014 concerning Regional Governments mention 3 (three) reasons for the dismissal of the Regional Head and/or vice, namely; death, own request, or dismissed. Unfortunately, this regulation only regulates dismissal because 'dismissed' but it does not provide any provision related to dismissal due to his 'request'.

Resignation regional head before the end of his tenure has had an unfavorable impact on the provincial government and the occurrence of political upheaval in the region. For example, the resignation of the vice governor of Jakarta, Sandiaga Salahuddin Uno (commonly called: Sandiaga Uno), became a candidate for a vice president to Prabowo Subianto.

Sandiaga Uno served as vice governor of Jakarta should have started from October 16, 2017, to October 16, 2022. However, when he was still in office for one year (August 9,2018 ), he is resigned to run in the presidential election. As a result, there was a vacant position as deputy governor for 21 months. These conditions have caused a political uproar about who has the right to replace the submitting party. The chaos between the supporting party (Gerindra and PKS) who has the right to fill the position, this condition has a negative impact not only in the administration of politics and government but also on public trust.

The resignation was also carried out by the regents and mayors such as Indramayu regent Anna Sopanah for reasons of difficulty in dividing time between taking care of family and government (Wijaya, 2018). Although in a different context, this condition is getting worse by the number of regional heads dismissed due to legal cases. The Ministry of Home Affairs noted, from 2004 to 2018, there were 434 Regional Heads affected by legal cases (Andayani, 2018). As a result of the involvement of the legal case, then automatically they dismissed before the end of his tenure. The dismissal of the regional head/vice before the end of his tenure in the perspective of democratic procedures, which is the principle of majority vote support, has damaged the trust of the voters.

Minister Tjahyo Kumolo responded to this phenomenon by reminding that the regional head and vice must be aware. Every vote that is obtained from their voters ethically and morally is an order that is genuinely and responsibly carried out when he has become the regional head (Setiadi, 2018). However, this reminder should also 
be accompanied by real policies because it is useless if no strict regulations are governing this matter.

This research is a response to the impact of dismissal of the regional head and/or vice, which has been legally elected. It has not only legal-political legitimacy but also social legitimacy. From a legal perspective, it is necessary to analyze the aspects of objectives and interests related to the regulation. In contrast, in the perspective of democracy based on support and trust, the resignation of the regional head or vice, whether the provincial, district or city heads have not yet finished their tenure. It seriously violates democratic values, damages the voters' trust, which has been channeled through the regional head election. Therefore, it is essential to reformulate the regulation related to the resignation of the regional head during their tenure.

Problems:

This research is built upon two problem formulations, first, how is the regulation related to the resignation of the regional head and/or vice in the perspective of legal politics? Second, how are the resignation of the regional head and/or vice seen from a democratic perspective?

Methods:

This research uses a juridical-conceptual approach with a multidisciplinary method. Furthermore, the data used in this research are secondary data such as books, regulations, journals, research reports, and other documents that are related to this research (Soekanto \& Mamudji, 2014). The secondary data is analyzed qualitatively on a juridical basis (legislation) and conceptually (democratic construction). So, the results will be obtained not only descriptive but also prescriptive.

\section{Results and Discussion}

\section{Heavy Requirements for Nominating Regional Head vis a vis Democracy Right}

The direct election for the regional head has brought significant and fundamental changes in the democratic perspective of the electoral process. The fundamental changes in the regional head election system are at least two things. First, the regional head election system is carried out directly by the people. Secondly, the nomination of the regional head can be resolve through a non-political party path (the independent path). In 2004, the enactment of Law No. 32 of 2004 concerning the Regional Government of Law No. 22 of 1999 has brought about a change in the regional head election system. The regional head is elected by the regional people directly. A legal change in democratic politics and the implementation of democratic regional head elections is a follow-up to changes in the constitution. Therefore, with the direct regional head election system, the essence of people's power in determining their leaders through elections and the people themselves will determine and choose who they want according to their choice (Saraswati, 2014). Although this system has 
a note because the Regional Representatives must propose the elected candidates, then the logic of the people's votes through direct elections can be annulled by the Regional Representatives. Still, at least this law has been a progression of the democratic transition process in the era of bureaucratic reform.

Besides, changes in the system of direct election of the regional head also change to the system of nominating regional head. The nomination of the regional head has opened and provided open spaces for citizens who want to run for regional head elections without having to go through political parties. Non-political party paths are often also called individual paths. This individual candidate is a necessity for political rights (participation), which has also guaranteed in Article 43 paragraph (1) of Law No. 39 of 1999 concerning Human Rights. It expressly states the rights of citizens not only to vote but also to be elected; thus, in the perspective of Human Rights, Indonesia no longer has a Relative Particularistic view but is more holistic (Saraswati, 2009). Thus the path of nominating a regional head can be taken using two paths, first the path of political parties and the second path of non-political parties (independent).

Both the paths of political parties and individual paths of the electoral law have determined the nomination requirements to be able to participate in regional head elections. However, both paths of nominating regional head by the electoral law are required to be quite heavy. This requirement also becomes more and more severe rather than lighter, especially the threshold requirements that must be met by candidates from parties and individuals.

Candidates for political parties or a combined of political parties in Law Number 32 of 2004 are required to meet a threshold of at least 15\% (fifteen percent) of the number of seats in the DPRD or 15\% (fifteen percent) of the accumulation of valid votes in the General Election of Regional Representatives members in the area concerned. This law does not yet provide specific conditions for individual candidates. Still, if you see the provisions of Article 58 paragraph (3), it is not so clear because it only states that political parties or combined political parties open as extensive opportunities as possible for individuals. The threshold then increased by Law Number 1 of 2015 concerning the Establishment of Government Regulations becoming 20\% (two twenty percent) of the total number of seats in the DPRD or 25\% (twenty-five percent) of the accumulation of valid votes in the general election of Regional Representatives members in the regions concerned. Whereas for individual candidates, the threshold requirements are as follows:

Table 1. Minimal Threshold based on Law No. 1 of 2015

\begin{tabular}{|l|l|l|}
\hline Position & Total Population & Minimal Threshold \\
\hline Governor & 2.000 .000 & $6,5 \%$ \\
\cline { 2 - 3 } & 2.000 .000 to 6.000 .000 & $5 \%$ \\
\hline
\end{tabular}




\begin{tabular}{|l|l|l|}
\hline \multirow{4}{*}{ Regent and Mayor } & 6.000 .000 to 12.000 .000 & $4 \%$ \\
\cline { 2 - 3 } & $>12.000 .000$ & $3 \%$ \\
\hline & 250.000 & $6,5 \%$ \\
\cline { 2 - 3 } & 250.000 to 500.000 & $5 \%$ \\
\cline { 2 - 3 } & 500.000 to 1.000 .000 & $4 \%$ \\
\cline { 2 - 3 } & $>1.000 .000$ & $3 \%$ \\
\hline
\end{tabular}

Not quite up there, in 2015 then the amendment regulation was issued, through Law Number 8 of 2015 concerning Amendment to Law Number 1 of 2015 concerning the Establishment of Government Regulation in Lieu of Law Number 1 of 2014 concerning the Election of Governors, Regents and Mayors Become a law that provides even more stringent conditions, especially for individuals, as follows:

Table 2. Minimal Threshold based on Law No. 8 of 2015

\begin{tabular}{|l|l|l|}
\hline Position & Total Population & Minimal Threshold \\
\hline Governor & 2.000 .000 & $10 \%$ \\
\cline { 2 - 3 } & 2.000 .000 to 6.000 .000 & $8,5 \%$ \\
\cline { 2 - 3 } & 6.000 .000 to 12.000 .000 & $7,5 \%$ \\
\cline { 2 - 3 } & $>12.000 .000$ & $6,5 \%$ \\
\hline Regent and Mayor & 250.000 & $10 \%$ \\
\cline { 2 - 3 } & 250.000 to 500.000 & $8,5 \%$ \\
\cline { 2 - 3 } & 500.000 to 1.000 .000 & $7,5 \%$ \\
\cline { 2 - 3 } & $>1.000 .000$ & $6,5 \%$ \\
\hline
\end{tabular}

The requirements for individuals which are already quite heavy have been made even worse by Law Number 10 of 2016 concerning Second Amendment to Law Number 1 of 2015 concerning the Establishment of Government Regulations in Lieu of Law Number 1 of 2014 concerning Election of Governors, Regents, And the Mayor Becomes an Act where previously the percentage threshold was only required for the population. Still, now the support conditions must be from residents who have the right to vote and included in the permanent voter list in the area concerned in the general election or the previous election. It is very undemocratic because there are many possibilities that a new age population can be listed on the permanent voter list 
after a general election or previous election. This provision considered to conflict with Law Number 2 of 2011 concerning Political Parties and also damages justice coveted by the public and protected by the 1945 Constitution of the Republic of Indonesia (Kardeli, 2018).

The Bulan Bintang Party (PBB) was affected by this threshold, because the Chairperson of the Regional Jakarta, Madsanih, was unable to run for Regional Head due to the clash with Article 40 paragraph (1) of Law Number 10 of 2016. Then he and the Legal Counsel Team submitted a judicial review to the Court Constitution (Machmudi, 2019).

Specifically, the provisions of this article have made it difficult for candidates to pitch as regional heads because of the threshold. Thus it can be said this is a form of restriction on access to democracy itself. In general, the concept of open democracy and multiple interpretations has become a boomerang for the implementation of democracy itself. Democracy is a form of commitment that should be maintained and implemented, an implementation that is not only procedural oriented but substantially oriented. Here then, awareness of democracy becomes a significant milestone. It is essential if the application of democracy without the support of democracy awareness itself will ultimately increase the tension of political arrogance (Isdiyanto, 2015). The way of thinking that must be built is substantial democracy (democratic by awareness) must be the foundation of procedural democracy (democratic by the system) rather than vice versa because it will suppress democratic values themselves.

As happened in Law Number 10 of 2016, especially the rules related to this threshold are considered to be very heavy so that they are instead counter-constructive to the objectives of the Regional Head Election directly, such as; 1). strengthen the position of regional head; 2). reduce Regional representative intervention so that it will reduce political transactions that give birth to "money politics"; 3 ). breaking the vertical link between political parties at the national level and political elites at the regional level; 4). Selected candidates are expected to have accountability, professionalism, and take sides with local society (N. M. Aziz, 2009).

However, the concept of direct elections that occur downstream (election by the people) but played upstream (policymakers) so that with the provisions of the threshold, then the goal is the quantity of democracy, not the quality of democracy. The problem is, democracy with political transactions and money politics will bring substantially undemocratic conditions. What is intended to be established is legal politics to direct prospective candidates who want to participate in elections preferring to use party or a combination of political parties because the conditions for individual candidates are getting more complicated and aggravated. Using a party or a combination of political parties brings consequences for political commitment to the party in addition to the constituents or voters. 
These severe conditions, instead of improving the quality of democracy, occur instead. Even though the issue of the high threshold cannot be seen as the quality of popular support, but such large public support cannot be interpreted as a form of involving the voters because it is only to fulfill the administrative requirements of symbolic support in the form of a photocopy of a sign residents who have been registered in the Permanent Voter List.

The quality of democracy deteriorates when many regional heads and/or their vice resign when their term of office has not finished and there is no single regulation prohibiting them from doing so. The actions of the elected regional head/vice if proposing to resign on their own will/either individually or perhaps jointly before the end of the tenure can be said to be an act that disappoints the public and is detrimental both in terms of financial and political support of voters who entrusted to him.

\section{Urgency of Adding Regulations to Resign as a Commitment to Democracy}

The loose regulations of the resignation of the regional head are one of the triggers for many of regional head/vice to resign during their tenure at both the provincial level (governor/deputy governor) and district/city level (regent/vice regent and mayor/vice mayor) lately is a result of the loosening of legal provisions about it. For example, in the records of the Ministry of Home Affairs at the district level: Vice Regent of Garut Regency of West Java; Dicky Chandra, Regent of Indramayu Regency of West Java; Anna Sophanah, while the provincial level was first carried out by Vice Governor of Jakarta; Priyanto in 2011 and subsequent vice-governor Sandiaga Uno in 2018 who nominated the vice president accompanied Prabowo Subianto. Legal politics that are built are still oriented towards political rights rather than political obligations as the goal of democracy. This product triggers a political system that is not oriented towards the people but is limited to the party. The political phenomenon itself is provoked into political lobbying which then leads to 'cartel' politics (Isdiyanto, 2016).

On the one hand, analyzing from a human rights perspective, the resignation of a regional head/vice regional head whatever the reason used is their right. Still, in the perspective of constituents, this can be seen otherwise. The right of the people to vote as Article 43 paragraph (1) of Law Number 39 of 1999 must be seen not only in the corridor of rights but also their obligations. This matter must be an essential concern because the conception of human rights in Indonesia is not an Islamic right but a progression with an Islamic obligation (Yasin, 2009). It can be seen in the provisions of Article 28J Paragraph (1) and (2) of the 1945 Constitution of the Republic of Indonesia.

From the perspective of democracy, a regional head and vice have support by a majority of voters. The election consumes a lot of state money; the potential for significant social conflicts is morally not good if he is going to resign before the tenure has not ended. However, there is a mechanism that must be taken if he is going to 
resign (Arjawinangun, 2018). Costs for democratic party activities are not small. The Ministry of Home Affairs noted that the total budget for elections to simultaneous regions for 2020 in 270 regions about to reach 15 (fifteen) trillion Rupiah (Yahya, 2020). Not to mention the risk of social conflict that always looms between supporters, as happened in the Jakarta elections. It becomes unfair if such a large amount of energy must simply evaporate with one of the regional heads or jointly resign.

People have a variety of criteria in selecting candidates for regional head candidates who compete. For example, the results of a study conducted by Mopeng (Mopeng, 2016) who examined voter behavior in choosing a regent in North Minahasa regency, where the results showed voters used sociology, psychological, and rationality benchmarks. The various benchmarks show that voters in determining the choice of the regional head are based on careful consideration, of course, also accompanied by high expectations of their choices if they are elected later. Therefore, direct regional head election as expanding political participation to create people sovereignty in electing regional leaders, thus it has strong political legitimacy (Hutapea, 2015).

Observing the resignation of regional head and vice when resigning before their tenure ends, there are several reasons, among others: family reasons used by the Regent of Indramayu district, not suitable with their partners, such as Dicky Candra Vice Regent of Garut who is paired with Aceng Fikri and Vice Governor of Jakarta; Prijanto who is paired with governor Fauzi Bowo, and for political reasons like following the contestation of other higher regional head elections or nominating in the presidential and vice-presidential elections such as the resignation by Joko Widodo while serving as Jakarta governor, Sandiaga Salahuddin Uno when he was Vice Governor of Jakarta.

The various reasons used to propose the resignation of the regional head/vice before the end of the tenure that is by considering the heavy requirements, the cost of the electoral process, the involvement of many parties, the impact on regional government, as well as the appearance of political upheaval. And the regional government should be stopped through regulation in regional government law.

The legal arrangement of the resignation of the regional head/vice before the end of the tenure, which is very loose, is causing much regional head/vice to propose to resign before their tenure ends.

Based on the provisions of Article 78, Paragraph (1) of Law No. 23 of 2014 is very clear, that the legal arrangements to resign the regional head/vice are very loose. The looseness of this arrangement is because it is a right, and there are no further provisions to prohibited resigning before the end of the tenure; therefore, it can be used as a basis for resigning. 
Regulations regarding the resignation are arranged in the Republic of Indonesia Government Regulation No. 18 of 2013 concerning Procedures for Resignation of Regional Heads, Deputy Regional Heads, and Public Servants Who Will Become Prospective Members DPR, DPD, Provincial DPRD, and Regency/City DPRD, As well as Conducting Leave of State Officials in Election Campaigns. However, it is also no urgency aspect of this regulation. On the contrary, this regulation limited to emphasizing that the Regional Head and/or vice could resign and obliged them to resign if they wanted to nominate themselves as candidates for DPR, DPD, DPRD, Province, or Regency/City. Not found a single article that complicates resignation.

The loosening regulation concerning the resignation of regional heads/vice before the end of their tenure, which until now has not received attention and study of political, sociological impacts and even losses borne by the state. Therefore, it is necessary to carry out a limited reconstruction of the terms of resignation by including the provisions of the legal terms and conditions prohibiting resignation before the end of the tenure except for specific reasons permitted by law. Politically law, the addition of this regulation, is nothing but to maintain democratic commitments so that there is a balance between rights and obligations as well as accommodating people's rights.

\section{Determination the pair of elected region head as the culmination process of submitting voter trust}

The determination of the winner of the regional head election shows the high support and trust of voters in them. Election of the regional head is an activity that unites three pillars of state life, which are the basis of the modern state, such as the pillars of democracy, state law, and human rights. The three pillars are united in the frame of regional head elections and general elections. The pillar of state law regulates, controls, and completes the implementation of the pillar of democracy to actualize the implementation of human rights.

The perspective of democracy, the election of regional heads (Pilkada) directly by the people as a reflection of the rights and sovereignty of the people are divested as people's participation in the political process of the election of the regional head, strengthening legitimacy, making closer relations between the leader. In short, the election of regional heads in the process of direct election of regional heads is the peak process of delivering the trust of voters to the regional head pair (Wardi, 2014).

One crucial sign of democracy in regional government is the change of regional leadership on a five-yearly basis. They were carried out peacefully, through a general, direct, free, secret, transparent, honest, and fair regional election mechanism that makes the election process and legitimate result or supported by the people.

The election of prospective candidate pairs of regional heads in the election contestation, which is followed by the determination of elected pairs, is politically interpreted as a surrender of the trust from voters. The choice of political voters to 
elected regional head pairs is at least based on their trust to them to be carried out according to a predetermined tenure, which is 5 (five) years. Legally this is also the legitimacy of democratic procedures that have consequences for rights and obligations that must be carried out.

The surrender of voter's trust to the elected regional head pair according to the principle of democracy culminates in the determination of the elected/winner candidate. Under the principles of democracy, the periodical of the head regional head must be carried out under the span of tenure, which is five years. If the elected has not finished his tenure, then resign for reasons beyond those specified in the law is an act that 'hurts' democracy. The value of democracy means the value of the most votes; thus, someone can be elected as regional head. The regional head or vice resigns before the end of the tenure is an act that hurts the trust of voters who have been voted through the regional head election.

Many critics of the democratic system in Indonesia, especially in the context of the election of regional heads and/or regional vice heads. The purpose of direct elections, whose initially to build substantial democracy to create capably and integrity leaders are then annulled by difficult and strenuous procedures, making it difficult to bring up candidates who are both capable and not entangled in political transnationalism. If not addressed carefully, the legal politics that are built could have shifted the people's sovereignty to become the sovereign of a political party, which incidentally can regulate regulation. Tito Karnavian, as the Minister of Home Affairs, also offered a discourse to evaluate the direct regional election, because many of the products were not under what was said to CNN Indonesia. "Not the opposite, it doesn't have integrity, doesn't have adequate capabilities, and the acceptability is low, but it has the contents of a [money] bag" (Indonesia, 2019).

Indonesia is based on a democracy-procedural-constitutional, then if legally legitimate, the election of the candidate is legitimate and cannot be contested. The exciting thing is, the lengthy and tiring process in the regional election process should or at least be balanced by the commitment of the leaders to the regions and delivering trust from the people to their representatives. As determined in the law, the actions of the regional head/vice who resigns before the end of his tenure if carried out for reasons other than due to the permanent illness so unable to carry out duties as regional head/vice, or because it is involved criminal/legal cases, are actions that hurt democratic values and waste the trust of voters.

\section{Resignation of the Regional Head during the Tenure in the Perspective of Political Law and Democracy}

The imbalance is the right word to describe a democratic process that is not fully democratic because between rights and obligations become biased. Democracy that only seen as a right is a crippled democracy that is trapped in the arrogance of power so that obligations become controls. The next phenomenon, which is not surprising, 
is that Indonesian democracy, in reality, is only dominated by the elite, and the direction of legal politics is structured to inhibit the development of democratic values (Burhani et al., 2019).

Strong legitimacy through direct elections does not make the democratic process run democratically. The escalation of the conflict that always heats up ahead of the elections is a barometer that the problem of democracy has not gone the way it should be. Democracy cannot stand alone in building 'healthy' Indonesian politics. At least there are 3 (three) basic principles which are the foundation, such as; the rule of law principles, constitutional principles, and the principle of democracy (Hajiji, 2013). The rule of law's state focuses on ensuring the implementation of a state that applies checks and balances and due process of law. At the same time, the constitutional principle is the application of the principle of legality in the officials' authority, institutions, or state institutions, and the principle of democracy is participation public.

Public participation becomes very important, not only in exercising political rights but also in its moral obligation in conducting oversight of state administration. Do not let the dominance of the elite who tend to maintain the status quo of oligarchic power instead used as a tool to suppress democracy formally-legally. Even a democratic system can produce anti-democratic products such as Hitler who is democratically elected but ultimately becomes anti-democratic (Isdiyanto, 2016).

The legal product itself, according to Mahfud MD, is strongly influenced by the political configuration in the circle of power, then politics is very determinant of the law (Md, 1998). Even according to Satjipto Rahardjo, politics has a more significant influence because the law is always in a weak position (Kurniawan, 2018) . Based on this underlying assumption, legal products that are still dominated by the interests of the elite who want to launch every need and political interest will be difficult to access by the public - especially in an apathetic and uncritical attitude.

Theoretical regulation of resignation democracy is very undemocratic because it does not describe the form of balance that should exist. Unfortunately, Law No. 7 of 2017 concerning General Elections indirectly legitimize this matter in its provision that the Acting Regional Head and/or vice must resign from his position and cannot be withdrawn if he wishes to participate in other political contestations such as becoming a member of the DPR, DPD, even the President/Vice President.

The voters in determining the choice of regional head pairs are also based on an excellent expectation for them to be able to lead their society and regions to bring progress, improve welfare, and the independence and competitiveness of their regional society. To be able to realize these conditions and expectations, sufficient time is required, under the periodization of the position determined by the law, which is five years. Voters who have given the legality of political positions to regional heads should be followed by the responsibility to their constituents. At least it can be 
measured based on dedication, such as carrying out his duties according to tenure (Arifulloh, 2015).

For regional head to realize the hopes and beliefs of these voters, the rule of law should obligate regional head/vice to carry out their regional office duties until the end of their tenure. It is intended so that the elected regional head pair in carrying out the duties and obligations of the continuity of the program can be measured. Likewise, the prohibition on regional head/vice in the regional government law should also be regulated on the prohibition to resign before the end of the tenure. The absence of rules regarding the prohibition of the resignation of a regional head/vice before the end of his tenure except for reasons permitted by legal regulations namely because of permanent illness and because of being involved in a legal case has been used as a reason for regional heads to resign before the end of the term of office.

An open recruitment system and nominating process define as any Indonesian citizen who submits or is submitted by a political party as long as it meets the specified conditions in an election contestation, whether the election of regents/mayors, governors, or presidents can take part in the contestation. As a result, not a few regional head/vice who resigned before the end of their tenure to participate in another election competition.

Some reasons for regional head/vice when submitting their resignation before the end of their tenure, include: due to family reasons, incompatibility with regional head, and political reasons such as will be contesting the election in other regions (provinces) or nominating in presidential/vice presidential elections. Therefore, it is correct if Tjahjo Kumolo stressed: "that the regional heads were elected through a very long process, starting from party recruitment to the campaign process and being elected, is a mandate given by the people that must be accounted for" (Carina, 2018).

Resignation of the regional head / vice-out of the reason determined by law because it is not prohibited has caused various problems in regional government and the implementation of the regional government. One of the problems as a result of the resignation of the vice governor Jakarta, Sandiaga Uno, has caused political upheaval and regional government for up to 11 months to determine his successor because there has not been an agreement between the bearer parties namely Gerindra and PKS. It is very hurtful to the people in a principle of democracy.

From the description above, it can be understood that the loose regulation of the resignation has been used as an excuse by regional head/vice. The amount of support and hope for the candidate pairs of regional head/vice with an election system that uses the principle majority becomes the central part for their success. Therefore, if there is a regional head/vice resign in his tenure out of the determining reasons, the law seriously harms the choices, hopes, and beliefs of the people who have chosen. 


\section{Conclusion}

With no regulation for regional head/vice to carry out his duties in the 5-year tenure and no regulation for regional head/vice to resign during his tenure has been used as an excuse to resign. Regulation of legal politics is still very pragmatic because, like the provisions of Article 29, Paragraph 1 of Law no. 32 of 2004 concerning Regional Government and after being replaced with the provisions of Article 78 paragraph 1 of Law no. 23 of 2014 concerning Regional Government. Even in the specific implementation provisions governing resignation as in Government Regulation No. 18 of 2013 also does not regulate the prohibition of resignation. Instead, it seems to facilitate and give way to it. It means, this can be seen that the political configuration that forms the basis of the political law of resignation as the Head of the Region and/or vice is still a preference to accommodate the rights and interests of political elites who seem oligarchic. The next effect is the potential for implementing a strong democracy or creating a democratic atmosphere that is balanced between political rights and political obligations morally to its constituents. Thus, from the perspective of democracy itself, this regulation is seen as undemocratic, and the regional head and/or vice is not a democrat. Suggestion: 1) A revision or addition of rules in Law No. 23 of 2014 concerning Regional Government related to the terms and conditions of the resignation of the Regional Head and/or vice when serving; 2) The principles of democracy must be essential to form regulations, which accommodate not only rights but also obligations. Therefore, if they insist on resigning just because they want to participate in another political contestation, it cannot be justified.

\section{References}

Akbar, I. (2017). Pilkada serentak dan geliat dinamika politik dan pemerintahan lokal Indonesia. CosmoGov: Jurnal Ilmu Pemerintahan, 2(1). https://doi.org/10.24198/cosmogov.v2i1.11852

Andayani, D. (2018). Mendagri: 434 Kepala Daerah terkena kasus hukum sejak 2004. Retrieved in Januari 1, 2020, from https://bit.ly/2GebjmT

Arifulloh, A. (2015). Pelaksanaan Pilkada serentak yang demokratis, damai dan bermartabat. Jurnal Pembaharuan Hukum, 3(3). http://dx.doi.org/10.26532/jph.v3i3.1376

Arjawinangun, K. (2018). Ini penjelasan Mendagri soal status Sandiaga Uno mundur dari Wagub. Retrieved in January 1, 2020, from https://bit.ly/3cugwDr

Aziz, M. A. (2016). Pilkada serentak melalui DPRD: sebuah gagasan mewujudkan Pilkada demokratis perspektif Pancasila dan UUD 1945. Politik Indonesia: Indonesian Political Science Review. https://doi.org/10.15294/jpi.v1i2.6582

Aziz, N. M. (2009). Pengkajian hukum tentang pemilihan kepala daerah. Jakarta: Badan Pembinaan Hukum Nasional Kementrian Hukum dan Hak Asasi Manusia Republik Indonesia. Retrieved from https://www.bphn.go.id/data/documents/pkj_pilkada.pdf

Burhani, M. L. M. A. M., Jendrius, J., \& Syahrizal, S. (2019). Relasi demokrasi, kekuasaan, dan politik hukum dalam pemilihan presiden dan wakil presiden 
tahun 2019. JPPUMA Jurnal Ilmu Pemerintahan Dan Sosial Politik Universitas Medan Area, 7(1), 1. https://doi.org/10.31289/jppuma.v7i1.2021

Carina, J. (2018). Mendagri Berharap tak ada lagi kepala daerah yang mundur karena masalah keluarga. Retrieved in Januari 1, 2020, from https://bit.ly/2Hn0I9R

Hajiji, M. (2013). Relasi hukum dan politik dalam sistem hukum Indonesia (legal and political relations in law system of Indonesia). Jurnal Rechtsvinding, 2(3). http://dx.doi.org/10.33331/rechtsvinding.v2i3.65

Hutapea, B. (2015). Dinamika hukum pemilihan Kepala Daerah di Indonesia. Jurnal Rechtsvinding, 4(1). http://dx.doi.org/10.33331/rechtsvinding.v4i1.136

Indonesia, T. C. (2019). Parpol dan calon tak mutu, problem utama ongkos mahal Pilkada. Retrieved in January 1, 2020, from https://bit.ly/3j9LzHe

Isdiyanto, I. Y. (2015). Prinsip umum demokrasi dan pemilu. Yogyakarta: Indie Book Corner.

Isdiyanto, I. Y. (2016). Rekonstruksi hukum dan ketatanegaraan Indonesia. Yogyakarta: UII Press.

Kardeli, S. D. (2018). Analisis tentang parliamentary threshold dan calon perseorangan berdasarkan Undang-Undang Nomor 10 Tahun 2016 dalam perspektif demokrasi dan prinsip check and ballances. Legality, 26(1), 118-129. https://doi.org/10.22219/jihl.v26i1.6618

Khakim, M. (2016). Undang-undang pornografi dalam tinjauan politik hukum pidana. Jurnal Hukum Novelty, 7(1), 43-56. http://dx.doi.org/10.26555/novelty.v7i3.a3933

Kurniawan, O. P. (2018). Pengaruh politik terhadap hukum. Jurnal Al-Maqasid, 4(1), 29-42. https://doi.org/10.24952/almaqasid.v4i1.1416

Machmudi, M. I. Al. (2019). Ambang batas pencalonan kepala daerah diujimaterikan di MK. Retrieved in January 1, 2020, from https://mediaindonesia.com/read/detail/260192-ambang-batas-pencalonankepala-daerah-diujimaterikan-di-mk

Md, M. (1998). Politik Hukum di Indonesia. Jakarta: LPE3S.

Mopeng, D. (2015). Perilaku pemilih pada pemilihan Kepala Daerah Minahasa Utara periode 2016-2021: Studi di Desa Sawangan, Kecamatan Airmadidi. Jurnal Politico, 4(2). Retrieved from https://bit.ly/3j4njp0

Santoso, T. (2007). Hukum dan proses demokrasi: problematika sekitar Pemilu dan Pilkada. Jakarta: Partnership for Governance Reform.

Saraswati, R. (2009). Calon perseorangan dalam pilkada suatu tinjauan filosofis. Jurnal Konstitusi, 2(1). Retrieved from https://bit.ly/3mOZB2Z

Saraswati, R. (2014). Reorientasi hukum Pemilukada yang mensejahterakan rakyatnya. Jurnal Dinamika Hukum. https://doi.org/10.20884/1.jdh.2014.14.2.303

Setiadi, S. (2018). Kenapa Kepala Daerah Berhenti di Tengah Jalan? Retrieved in January 1, 2020, from https://beritagar.id/artikel/editorial/kenapa-kepaladaerah-berhenti-di-tengah-jalan

Soekanto, S., \& Mamudji, S. (2014). Penelitian hukum : suatu tinjauan singkat. PT. Raja 
Grafindo.

Wardi, R. (2014). LIPI: Pilkada Langsung Mencerminkan Kedaulatan Rakyat. Retrieved in Januari 1, 2020, from http://lipi.go.id/lipimedia/lipi:-pilkadalangsung-mencerminkan-kedaulatan-rakyat/10263

Wijaya, W. (2018). Bupati Indramayu Mundur, Mendagri: Preseden Buruk Bagi Pemerintahan Indonesia. Retrieved January 1, 2020, from https://bit.ly/2FYdyek

Yahya, A. N. (2020). Kemendagri: total anggaran Pilkada 2020 Rp 15 triliun. Retrieved January 1, 2020, from https://bit.ly/3hYPKUB

Yasin, J. (2009). Hak azasi manusia dan hak serta kewajiban warga negara dalam hukum positif Indonesia. Syiar Hukum, 11(2), 1-18. Retrieved from https://ejournal.unisba.ac.id/index.php/syiar_hukum/article/view/541 